\title{
Dissecting the Epistemological Underpinnings of Lockean Thought: $A n$ Essay Concerning Human Understanding Perspective
}

\author{
Nde Paul Ade ${ }^{1 *}$
}

${ }^{1} \mathrm{Ph} . \mathrm{D}$, Department of Philosophy, University of Bamenda, Bamenda, Cameroon

DOI: $10.36348 /$ jaep.2022.v06i01.005

| Received: 13.12.2021 | Accepted: 19.01.2022 | Published: 28.01 .2022

*Corresponding author: Nde Paul Ade

Ph.D, Department of Philosophy, University of Bamenda, Bamenda, Cameroon

\section{Abstract}

This paper aims at uncovering and fragmenting the foundations of Locke's theory of knowledge as addressed in An Essay Concerning Human Understanding. Systematically, it reveals the origin of knowledge, develops and evaluates the limits of human knowledge and the extent of understanding, as well as critically examines what is knowable with more emphasis on certain and probabilistic grounds. Certainty is attainable through two principal means, comprising the use of the human senses and adoption of abstract reasoning. The sources of human knowledge are significant in easing and enhancing our knowledge of God as it facilitates the justification of his existence, portraying orderliness in the world, and positing mankind as part of God's creatures expected to implement moral lifestyles through the appeal to reasoning as a law of nature even when in a state of nature. The value of this principle is evident for self-preservation, including an essential moral obligation for the preservation of everybody. The ethical basis of the state of nature featuring both moral and natural laws, signals the natural moral nature of man as determined by a rational order designed by a rational and knowable God.

Keywords: God, Knowledge, Locke, Man, Nature, State, Theology, Understanding.

Copyright (C) 2022 The Author(s): This is an open-access article distributed under the terms of the Creative Commons Attribution 4.0 International License (CC BY-NC 4.0) which permits unrestricted use, distribution, and reproduction in any medium for non-commercial use provided the original author and source are credited.

\section{INTRODUCTION}

Over the years, various thinkers from different schools of thought have attempted to uncover the hidden realities of the past, present and future expectations about the world in which we live. A majority of these realities constitute the sources, nature, and theories of knowledge. From this context, Locke's contributions to epistemology could neither be under rated nor considered as an exemption, especially given the fact that, his ideas as elaborated in his An Essay Concerning Human Understanding [1], revealed something different from held thoughts connected to knowledge. From a sixteenth century context, following the devastating effects of the wars of Religion, secularization as a political thought system predominantly preoccupied thinkers like Machiavelli, Hobbes [2], Montesquieu [3], and Locke, whose roles influenced philosophy significantly due to their breaking of Religion and Theology, thereby paving the way for the introduction and growth of more rational ideas that contributed in paralyzing the authority of the church which characterized such an epoch. Systematically, Locke's Essay serves as a catalyst as it provides varied interpretations and understandings of the foundations of knowledge, including more emphasis on early modern English theistic thought systems. Therefore, the major basis of Lockean epistemology centers on theological foundations [4], without which the realization of a clear-cut revelation of the real origins of knowledge would have either been a farfetched venture or unattainable to a greater extent.

Unlike the classical thinkers who hold the view that nature constitutes the finality of mankind, modern thinkers on their part firmly believe that nature is closely connected to the origins of humanity. This justifies the reason for which Strauss [5] considers selfinterest as a portrayal of atheism similar to the original perspectives of the state of nature involving the situation of humanity in the pre-political or social context of existence as easily advanced and distinguished from the ideas of social contract theorists like Hobbes, Locke, Rousseau, Montesquieu, among others. Emphatically, Locke posits a state of nature based on theological differences, giving room for questioning human situations, precisely on how man came into existence, the nature of humans, as well as the authentic nature of the author of creation (God). 
Nde Paul Ade., J Adv Educ Philos, Jan, 2022; 6(1): 30-36

Assessing these aspects ensures a better understanding of modernity as shown through a thorough examination of Religion, Theology, secularization, and Christianity, considered as relevant domains that facilitated the emergence of new thought provoking philosophical ideas of modernization.

\section{The Cons of Innate Ideas and Rejection of Reason as Basis of True Knowledge}

The manner of knowing things in their real nature and the possibility or impossibility of attaining a certain degree of truth occupy a central position in Locke's philosophy because knowledge about humans, non-humans, including experiences of the external world can mostly be reliably guaranteed by adopting a coherent and rigorous systematic thought system that eases the possibility of knowledge attainment. From Locke's Essay, being his major epistemological text, he unveils the significance of addressing pertinent issues linked to originality, truth, certainty, and the extent to which beliefs, opinions, and human knowledge as a whole can go when he writes in Book One, Chapter One of the An Essay Concerning Human Understanding: "being my purpose to enquire into the original, certainty and extent of humane knowledge; together with the grounds and degrees of belief, opinion and descent" 6. After a total condemnation of the reliance and belief in innate ideas, Locke proceeds by stating the origin of the manner in which various things become knowable, basing on sensation, reflection, as well as on the character of things through an exploration of ideas. To further buttress this view, a clearer intention of dismissing innatism is revealed by Locke when he regards innate ideas as those "stamped" on peoples minds which produce falsehood, insufficiency, and unfit to attain certainty, truth, or knowledge as he indicates:

"It is an established opinion among some men, that there are in the understanding certain innate principles; some primary notions, characters, as it were stamped upon the mind of man; which the soul receives in its very first being, and brings into the world with it. It would be sufficient to convince unprejudiced readers of the falseness of the supposition, if I should only show how men, barely by the use of their natural faculties may attain to all the knowledge they have, without the help of any innate impressions and may arrive at certainty, without any such original notions or principles" [6].

Moreover, the main tenet of this declaration lies in disagreeing with thinkers such as Descartes [7], who strongly believes that a greater degree of human knowledge is inborn, or better still, that initially, humans were endowed with knowledge that is independent of human experiences. Nevertheless, Locke's rationale was intended to justify that human knowledge as possessed by mankind is derived from experience and not from innatism, given that, natural faculties like senses of taste, touch, feel, smell, hear, and vision, constitute various means of experiencing and attaining knowledge of the world as a whole. Similarly, Locke adds from Book One, Chapter Two of the Essay that, "if it were true in matter of fact, that there were certain truths wherein all mankind agreed; it would not prove them innate". Hence, it follows that, no principles exist to which humans universally adhere to, since the law of identity (whatsoever is, is) coupled with the law of non-contradiction (it is impossible for the same thing to be and not to be) are revealed. Moreover, it is believed that some categories of people such as children and mentally deranged persons do not understand the basic and universal maxims earlier highlighted. This is evident from the grounds that, children and idiots have no apprehension or understanding of such thought which disqualifies its universal character as Locke admits in Book One, Chapter Two: "it is evident that all children and idiots have not the least apprehension or thought of them. And the want of that is enough to destroy that universal assent which most needs be the necessary concomitant of all innate truths".

In a similar manner, Locke disagrees with the appeal to reason as a suitable tool for discovering and revealing particular truths as he considers reason as, nothing else but the act of drawing unknown truths from rules or propositions which are already discovered, coupled with the belief that, the discovery of truth about visible objects does not need to appeal to any initial or original knowledge before it is rendered possible to be perceived by it. Supporting this perspective, Locke advances in his Book One, Chapter Two of the Essay as follows: "But how can these men think the use of reason necessary to discover principles that are supposed innate, when reason (if we may believe them) is nothing else but the faculty of deducing unknown truths from principles or propositions that are already known?", adding that, innate ideas are not derived from reason and do not in any way owe their existence from reason as he states in Book One Chapter Two:

"unless, as I have said, we will have all the certain truths that reason ever teaches us, to be innate. We may as well think the use of reason necessary to make our eyes discover visible objects, as that there should be need of reason, or the exercise thereof, to make the understanding see what is originally engraved on it, and cannot be in the understanding before it is perceived by it. So that to make reason discover those truths thus imprinted, is to say, that the use of reason discovers to a man what he knew before; and if men have those innate impressed truths originally, and before the use of reason, and yet are always ignorant of them till they come to the use of reason, it is in effect to say, that men know and know them not at the same time" [8].

Focusing on this desire to discover innatism through reason, it is believed that if innate principles actually do exist, then, it will be worthless learning 
Nde Paul Ade., J Adv Educ Philos, Jan, 2022; 6(1): 30-36

about them. In other words, it will be fully contradictory stating that, "men both know and do not know things at the same time" which is practically farfetched and even impossible.

\section{Against Innate Moral Knowledge and Prioritization of Experience}

Chapter Three of Locke's Essay which centers on the denial of innate moral knowledge equally emphasizes on the impossibility for everyone to accept certain moral rules unanimously and universally [9]. To buttress this perspective, Locke categorically states that no apriori ideas do exist, even including those connected to the knowledge of God by pointing out that, "the truest and best notions men have of God were not imprinted, but acquired by thought and meditation, and a right use of their faculties: Since the wise and considerate men of the world, by a right and careful employment of their thoughts and reason, attained true notions in this as well as other things" [9]. That notwithstanding, it is worth noting that, Locke does not implies rejecting God or knowledge of God, but it highlights the belief according to which knowledge of God is not derived instinctively, since the possibility of knowing God is attainable through the appeal to reason.

However, since it is possible for man to acquire knowledge, it is worth stating that the manner of knowledge attainment to Locke is limited rigorously to all experience acquired which includes the use of the senses or reflection as elaborated as follows: "Let us suppose the mind to be, as we say, white paper, void of all characters, without any ideas: How comes it to be furnished? Whence comes it by that vast store which the busy and boundless fancy of man has painted on it with an almost endless variety? Whence has it all the materials of reason and knowledge?" [10]. A categorical answer to these questions refers to one term which is from "Experience", considered as the only means from which all human knowledge is founded and from where it derives its reality. Furthermore, observations applied either on external sensible objects or on internal operations of the mind as manifested by humans, are accountable for supplying necessary materials for understanding and thinking which are termed as "The two fountains of knowledge, from whence all the ideas we have, or can naturally have, do spring" [10].

\section{DISCUSSIONS}

It is worth pointing out that, human faculties are tools that permit us to conceive clearer ideas about things, thereby allowing us to perceive the world concretely. Although humans are born with natural faculties permitting them to learn about people and things, the mind is described as a "blank slate" or white paper, that is, void of character (tabula rasa). Here, Locke concurs that, either internal or external knowledge originates from our experiences, especially through the senses comprising human faculties fit for perceiving and interacting with the external world through touch, taste, feel, smell, sight, and hearing or knowledge will be far reaching. A typical example of the value and role of the senses involve: First, the senses are acquainted about specific sensible objects and they help in transmitting many distinct conception of things into the mind. Second, the senses provide us with knowledge of colours, heat, cold, hard, soft, bitter, sweet, and all other aspects of sensible natures or qualities. Third, a majority of most of the ideas we possess are derived from the senses which convey and create perceptions about external objects in the mind as Locke writes:

"Our senses, conversant about particular sensible objects, do convey into the mind several distinct perceptions of things, according to those various ways wherein those objects do affect them... When I say the senses convey into the mind, I mean, they form external objects that produce perceptions. This great source of most of the ideas we have, depending wholly upon our senses, and derived by them to the understanding, I call sensation" [11].

Moreover, closely following sensory knowledge stemming from human experimental abilities is reflection, involving internal experience and the manifestation of mental operations. Attaining the reflective stage requires more training and attention, given that it is a more developed faculty compared to sensory knowledge. Also, reflection is vital in providing supplementary knowledge about internal functions in throwing more light on how to react amidst given circumstances as well as in determining the manner of perceiving the world.

In relation to the value of reflection, it equips and eases understanding with a set of ideas and equally renders perception, willing, knowing, thinking, doubting, believing, and reasoning, just to name these few, as distinct entities as Locke adds: "the perception of the operations of our own mind within us, as it is employed about the ideas it has got, which operations, when the soul comes to reflect on and consider, do furnish the understanding with another set of ideas which could not be had from things without". Added to the ways of attaining understanding are "the source of ideas every man has wholly in himself; and though it be not sense, as having nothing to do with external objects, yet it is very like it, and might properly enough be called internal sense" [11].

\section{Understanding the Nature of Ideas and Limits of Knowledge}

Sensation and reflection contribute immensely in impacting ideas in the mind which Locke attempts defining as "Whatever is meant by phantasm, notion, species, or whatever it is which the mind can be employed about in thinking" [12]. To add, ideas signify whatever involves the basis each time one thinks, including things as portrayed by the senses, theoretical 
Nde Paul Ade., J Adv Educ Philos, Jan, 2022; 6(1): 30-36

concepts, as well as things that inhabit our minds. The two major ideas include simple ideas (single things such as the direct feeling of cold being isolated and particular) and complex ideas (combining simple ideas and treating them together). Worthy of note is that, complex ideas derive from the assembling of simple ideas and comparing various ideas [13].

However, simple ideas are passive in nature whereas complex ideas are active since they involve the use of human faculties. The remaining parts of Book Two of Locke's Essay emphasize on the features of complex ideas like time, motion, space, duration, infinity, substance, and God [14]. Here, it is worth revealing that, Locke excludes metaphysical grounds while addressing the epistemological underpinnings of his philosophy. Nonetheless, the absence of the origin of natural faculties, lack of knowledge on the existence of the external world and the extent to which knowledge could be termed reliable are unexamined in Books One and Two of the Essay.

Beyond what is knowable and how things ought to be known, it is incumbent to reveal the things that cannot be known through experience (sensation and reflection). In unveiling the limits of human knowledge and non-existence of innate ideas, Locke adds:

"I suppose it may be of use to prevail with the busy mind of man to be more cautious in meddling with things exceeding its comprehension; to stop when it is at the utmost extent of its other; and to sit down in the quiet ignorance of those things which, upon examination, are found to be beyond the reach of our capacities. We should not then perhaps be so forward, out of an affection of an universal knowledge, to raise questions, and perplex ourselves and others with disputes about things to which our understandings are not suited" [6].

Here, it is evident that certain things cannot be easily known by man due to the imperfections and limitations of human faculties. But then, in identifying and acknowledging the shortcomings of the knowable things, it is worth adding that, humans can still attain some degree of knowledge in order not to tempted to dive into skepticism as Locke warns, "when we have well surveyed the powers of our own minds, and make some estimate of what we may expect from them, we shall not be inclined either to sit still, and not set our thoughts on work at all, in despair of knowing anything, nor on the other side, question everything, and disclaim all knowledge, because some things aren't to be understood" [11]. However, the specific kind of knowledge expected is that which is geared at a convenient lifestyle and tilted towards virtue. Again, the origin of knowledge from this standpoint is God, being the author of necessary things that make life worth living according to his will as Locke quotes: "though the comprehension of our understanding comes exceeding short of the vast extent of things, yet we shall have cause enough to magnify the bountiful author of our being, for that proportion and degree of knowledge he has bestowed on us, so far above all the rest of the inhabitants of this our mansion. Men have reason to be well satisfied with what God hath thought fit for them, since he hath given them" [12].

\section{Knowledge versus Belief}

Book Four of the Essay, precisely from the coinage "Of Knowledge and Opinions", Locke demarcates knowledge and belief, terming knowledge as, "the perception of the agreement or disagreement of two ideas". That is, the act of merely revealing agreement or disagreement in the mind [13]. Furthermore, the first chapter of the Essay reveals four types of knowledge. First, knowledge of identity and diversity involving a comparison of ideas comprising simple knowledge. Second, relational knowledge, based on the connection between two ideas. Third, knowledge of coexistence, also understood as knowledge involving similarities and fourth, knowledge of real existence is comprising a relation between ideas and realities in the world [14]. From this context, knowledge is attained either intuitively, demonstratively, or through sensation. Through intuition, a direct grasping of agreement or disagreement of ideas is obvious, which is unopened to doubt, hesitation or examination, though it is difficult to attain.

Demonstrative knowledge, on its part, consists of a situation where the mind perceives agreement or disagreement of ideas but not immediately [15]. So, this form depends on the use of proofs to establish agreement whenever disagreement exists. It is important to underscore that, since demonstration relies mainly on proofs, it must be ensured that no part is left out un-scrutinized, especially when treating longer deductions that may not easily be retained subsequently. Thus, it follows that, men often embrace falsehood during demonstrations, thereby rendering it more imperfect than intuitive knowledge [15]. Lastly, sensitive knowledge which establishes knowledge of external things contains a level of certainty, even when we are unaware of what the senses portray. Worth stating is the fact that, the distinctions, limits, and variations of the types of knowledge, disqualify human understanding and knowledge in general, especially when addressing things that could be known with absolute truth as Locke indicates:

"From all which it is evident, that the extent of our knowledge comes not only short of the reality of things, but even of the extent of our own ideas. Though our knowledge be limited to our ideas, and cannot exceed them either in extent or perfection...I think I may, without injury to human perfection, be confident, that our knowledge would never reach to all we might desire to know, concerning the ideas we have, nor be able to surmount all the difficulties, and resolve all the questions that might arise concerning any of them" [16]. 
Nde Paul Ade., J Adv Educ Philos, Jan, 2022; 6(1): 30-36

Given that the achievement of absolute certainty by human abilities is practically impossible and rare to realize, it is better to focus more on particular expectations for the realization of certainty about the world. This paves way for belief and opinion to set in for the justification of epistemic principles and adoption of norms. Knowledge embodies certainty and is uncommon, belief stems from probability and appeals to reason so as to evaluate the tenability of ideas, grounds, and assertions. Though the attainment of complete knowledge is far-fetched, Locke still advances the possibility of realizing sufficient human knowledge when he quotes: "The understanding faculties being given to man, not barely for speculation, but also for the conduct of his life, man would be at a great loss, if he had nothing to direct him, but that has the certainty of true knowledge. For that being very short and scanty, as we have seen, he would be often utterly in the dark, and in most of the actions of his life, perfectly at a stand, had he nothing to guide him in the absence of clear and certain knowledge" [17].

Following Lockean perspective, it is obvious that, human relation with God and knowledge of a creator signals another possibility for man to access epistemic knowledge as well as in determining the manner of living and acting within the society. The abilities to reason, judge, demonstrate, and argue, were placed by God on man. To buttress this belief, in relation to judgment, Locke considers as:

"What God has given man to supply the want of clear and certain knowledge, in cases where that cannot be had, is judgment: whereby the mind takes its ideas to agree or disagree, or which is the same, any proposition to be true or false, without perceiving a demonstrative evidence in the proofs. The mind sometimes exercises this judgment out of necessity, where demonstrative proofs and certain knowledge are not to be had, and sometimes out of laziness, unskillfulness, or haste, even where demonstrative proofs are to be had" [17].

\section{Distinguishing Probability from Demonstrative Knowledge}

Demonstrative knowledge results to absolute certainty, whereas, probability simply reveals likeliness of a thing. This leads to belief, assent or mere opinions, which Locke describes as "the act of admitting or receiving any proposition for true, because of arguments or proofs that are found to persuade us to receive it as true, without certain knowledge that it is so" [18]. Moreover, in order to justify the acceptance of beliefs, Locke prescribes the adoption of degrees of assent as a way of moderating and controlling judgments and opinions, , giving more room for trusting some beliefs and opinions, though they cannot be known as true or certain. The first degree of assent being that which links ones personal experiences with those of others, the second, involving testimonies from others about the things we did not experience. To Locke, the first degree is preferable because it involves fair witnesses and is more reliable and believable when he writes: "The first and the highest degree of probability, is, when the general consent of all men, in all ages, as far as it can be known, concurs with a man's constant and never failing experience in like cases, to confirm the truth of any particular matter of fact attested by fair witnesses: such are all the stated constitutions and properties of bodies, and the regular proceedings of causes and effects in the ordinary course of nature. This we call an argument from the nature of things themselves" [19].

Despite the fact that the first degree assent is not as valuable as the second, it could be regarded as more practical, not to say absolutely certain. However, the second still permits one to act as well as respond to beliefs as it provides a degree of confidence, though Locke cautions how man must act about testimonies and condemns beliefs on trust in tradition when he writes: "the next degree of probability is, when I find by my own experience, and the agreement of all others that mention it, a thing to be for the most part so, and that the particular instance of it is attested by many and undoubted witnesses" [19]. Locke's rationale here is that, through judgment and probability, practical certainty and the provision of necessary information about life and virtue can be realized.

\section{The Inseparability of Epistemology and Politics}

Given that Locke prescribes how one ought to live, it renders his epistemology inseparable from his politics, as he unveils the dangers of false epistemology in the following declaration:

"I cannot but own, that men's sticking to their past judgment, and adhering firmly to conclusions formerly made, is often the cause of great obstinacy in error and mistake. But the fault is not that they rely on their memories for what they have before well judged, but because they judged before they had well examined... What we once know, we are certain it is so: and we may be secure, that there are no latent proofs undiscovered, which may overturn our knowledge, or bring it in doubt. But, in matters of probability, its not in every case we can be sure that we have all the particulars before us, and that there is no evidence behind, and yet unseen, which may cast the probability on the other side, and outweigh all that at present seems to preponderate with us" [19].

\section{CONCLUSION}

From the afore examined contributions to epistemology, it is important to underscore the main rationale of Locke's theory of knowledge as initially determined and shaped by theological contrarieties as elaborated in his An Essay Concerning Human Understanding. In exploring Lockean ideas, the inadequacies of human knowledge, including things that can be known with certainty and probabilistically are evoked. For instance, basic things are easily known and understood thanks to the senses and reflection. 
Nde Paul Ade., J Adv Educ Philos, Jan, 2022; 6(1): 30-36

Also, justifying God's existence, way of life, moral lifestyles, and orderliness in the universe becomes possible due to the role of natural human faculties. So, if Locke is still very influential in this modern, complex, pluralistic politically dominated thought system, it is partly because of his realism consisted in fragmenting the human situation without solely relying on religious doctrines as Forster indicates [20]. As a key liberalist, addressing issues linked to property rights, tolerance, and faith, influenced subsequent thinkers and political life of contemporary societies religiously, culturally, politically, and philosophically as highlighted by Strauss [5] and Pangle [21].

However, philosophy, being a better tool for understanding the world and human life better, it equally serves as a means of serving the world in order to reflect God's goal for humanity as advanced by Gillepsie [22]. Though Laslett thinks that, Locke's political thought is incoherent as a result of his incorrect claims about human nature and the natural world [23], similar to Dunn's questioning of Locke's proofs of God's existence especially based on the pluralistic and present Christian society perspective [24]. It is worth out that, placing false certainty on beliefs is uncalled for, since many opinions usually become uncertain and untrue. The wars, violence, persecutions, and destructions that characterized Locke's era were partly due to the varied opposing belief systems of various parties, sweeping across Europe, linked to the justification of truth, hampered peace, humanity, friendship, human rights, and even the diversity of opinions as Dunn, Tully, and Arsleff indicate [24-26].

The adverse effects of the opposing beliefs pushed Locke to warn against fanaticism in chapter nineteen titled "Of Enthusiasm" when he states: "Their minds being thus prepared, whatever groundless opinion comes to settle itself strongly upon their fancies is an illumination from the spirit of God, and presently of divine authority: And whatsoever odd action they find in themselves a strong inclination to do, that impulse is concluded to be a call or direction from heaven and must be obeyed: It is a commission from above and they cannot err in executing it. This I take to be proper enthusiasm, which, though founded on reason not divine revelation, but rising from the conceits of a warmed or overweening brain, works yet, where it once gets footing more powerfully on the persuasions and actions of men..." [27]. Following this analysis, it is evident that, unnecessary and unquestioned acceptance of beliefs, precisely religious, leads to fanaticism and pushes people to adopt inhumane actions. Consequently, all beliefs need to undergo proper scrutiny and open to judgment and rationality, considering the complexity of achieving certainty. Humans are neither omniscient nor omnipotent due to their inability to possess ultimate or full knowledge of people and things as Devine [28] evokes as an attempt to merge virtue with human freedom.

\section{REFERENCES}

1. Locke, J. (2008). An Essay Concerning Human Understanding, New York, Oxford University Press.

2. Hobbes, T. (2010). Leviathan, Cambridge, Cambridge University Press.

3. Montesquieu, B. (1948). Lettres Persanes, Paris, Librairie Droz.

4. Locke, J. (1958). The Reasonableness of Christianity, London, A \& C Black Limited.

5. Strauss, L. (1988). What is Political Philosophy? Chicago, University of Chicago Press.

6. Locke, J. (2008). An Essay Concerning Human Understanding, New York, Oxford University Press, Book 1 Chapter 1.

7. Descartes, R. (1970). Discourse on Method, Paris, PUF.

8. Locke, J. (2008). An Essay Concerning Human Understanding, New York, Oxford University Press, Book 1 Chapter II.

9. Locke, J. (2008). An Essay Concerning Human Understanding, New York, Oxford University Press, Book 1 Chapter III.

10. Locke, J. (2008). An Essay Concerning Human Understanding, New York, Oxford University Press, Book II Chapter I.

11. Locke, J. (2008). An Essay Concerning Human Understanding, New York, Oxford University Press, "Introduction".

12. Locke, J. (2008). An Essay Concerning Human Understanding, New York, Oxford University Press, Book II Chapter XII.

13. Locke, J. (2008). An Essay Concerning Human Understanding, New York, Oxford University Press, Book II Chapter 12-33.

14. Locke, J. (2008). An Essay Concerning Human Understanding, New York, Oxford University Press, Book II Chapter XXIII.

15. Locke, J. (2008). An Essay Concerning Human Understanding, New York, Oxford University Press, Book IV Chapter II.

16. Locke, J. (2008). An Essay Concerning Human Understanding, New York, Oxford University Press, Book IV Chapter III.

17. Locke, J. (2008). An Essay Concerning Human Understanding, New York, Oxford University Press, Book IV Chapter XIV.

18. Locke, J. (2008). An Essay Concerning Human Understanding, New York, Oxford University Press, Book IV Chapter XV.

19. Locke, J. (2008). An Essay Concerning Human Understanding, New York, Oxford University Press, Book IV Chapter XVI.

20. Forster, G. (2005). John Locke's Politics of Moral Consensus, New York, Cambridge University Press.

21. Pangle, T. (1988). The Spirit of Modern Republicanism: The Moral Vision of the American Founders and the Philosophy of Locke, Chicago, University of Chicago Press. 
Nde Paul Ade., J Adv Educ Philos, Jan, 2022; 6(1): 30-36

22. Gillepsie, M. (2008). The Theological Origins of Modernity, Chicago, University of Chicago Press.

23. Laslett, P. (2009). "Introduction". Two Treatises of Government, Cambridge, Cambridge University Press.

24. Dunn, J. (1969). The Political Thought of John Locke, Cambridge, Cambridge University Press.

25. Tully, J. (1980). A Discourse on Property: John Locke and his Adversaries, Cambridge, Cambridge University Press.
26. Arsleff, H. (1969). "The State of Nature and the Nature of Man in Locke", John Locke: Problems and Perspectives, Cambridge, Cambridge University Press, 99-136.

27. Locke, J. (2008). An Essay Concerning Human Understanding, New York, Oxford University Press, Book IV Chapter XVIV.

28. Devine, D. (1978). "John Locke: His Harmony Between Liberty and Virtue", Modern Age, 246257, http://www.mmisi.org/MA/22-03/devine.pdf. 